\title{
EVALUASI TEKNIS KINERJA \\ BANGUNAN PENGENDALI LAHAR TUKAD UNDA PASCA ERUPSI GUNUNG AGUNG TAHUN 2017
}

\author{
I Gst. Lanang M Parwita ${ }^{(1)}$, Made Mudhina ${ }^{(2)}$, I Wyn. Intara ${ }^{(3)}$, I Wyn. Sudiasa ${ }^{(4)}$ \\ 1,2,3,4 Dosen Jurusan Teknik Sipil, Politeknik Negeri Bali, Kampus Bukit Jimbaran,Tuban Badung -Bali \\ P.O Box 1064, email: \\ gstlanangmadeparwita@pnb.ac.id
}

\begin{abstract}
ABSTRAK
Peristiwa erupsi Gunung Agung yang terjadi akhir tahun 2017 telah berdampak terhadap berbagai hal dan salah satunya terhadap beberapa bangunan pengendali lahar yang ada di sepanjang alur sungai. Beberapa bangunan masih tetap dalam kondisi baik namun beberapa bangunan kondisinya menjadi rusak ringan, rusak sedang bahkan rusak berat sehingga fungsinya tidak bisa seperti semula. Sementara di bagian lainnya inventarisir bangunan yang ada serta evaluasi kinerjanya belum terpetakan dengan baik. Target khusus dari penelitian ini adalah terinventarisasinya bangunan untuk selanjutnya menjadi dasar dalam melakukan evaluasi kinerja yang menjadi data yang sangat penting bagi instansi terkait terutama Balai Wilayah Sungai Bali Penida dalam melakukan operasi dan pemeliharaan bangunan pengendali lahar.

Metode penelitian ini menerapkan metode analisis kwantitatif berdasarkan pengumpulan data primer dan skunder baik melalui pengukuran langsung di lapangan maupun dengan studi literatur.

Jumlah bangunan pengendali lahar yang terdapat di sepanjang alur Tukad Unda sebanyak 9 buah. Berdasarkan jenis bangunan yang ada maka bangunan tersebut dibagi menjadi 3 buah jenis yaitu Check Dam sebanyak 6 buah dengan 2 buah type lubang dan 4 buah type tertutup, 2 buah jenis konsolidasi Dam dan 1 buah jenis dinding penahan tanah. Berdasarkan analisa hidrologi menunjukkan R2 $=99,56 \mathrm{~mm}$, R5 $=110,56 \mathrm{~mm}, \mathrm{R} 10=115,21 \mathrm{~mm}, \mathrm{R} 25=127,56 \mathrm{~mm}, \mathrm{R} 50=138,41 \mathrm{~mm}$ dan $\mathrm{R} 100=141,56 \mathrm{~mm}$. Sementara debit banjir rancangan Q2 $=150,23 \mathrm{~m}^{3} / \mathrm{dt} . \mathrm{Q} 5=165,36 \mathrm{~m}^{3} / \mathrm{dt}$. Q10 $=173,47 \mathrm{~m}^{3} / \mathrm{dt}$. Q25 $=$ $182,03 \mathrm{~m}^{3} / \mathrm{dt}$. Q Q $50=187,29 \mathrm{~m}^{3} / \mathrm{dt}$ dan Q100 $=192,16 \mathrm{~m}^{3} / \mathrm{dt}$. Hasil analisa kapasitas bangunan menunjukkan bahwa semua bangunan mampu melewatkan debit banjir kala ulang 25 tahunan. Ini disebabkan beberapa hal yaitu penampang bangunan yang besar, kemiringan sungai yang tinggi serta kondisi DAS yang masih bagus. Hasil evaluasi teknis kinerja bangunan menunjukkan 8 dari 9 buah bangunan yang ada dalam kondisi yang baik memiliki kinerja diatas $80 \%$. Sementara satu bangunan chek dam mengalami rusak berat karena terbawa hanyut oleh erupsi tahun 2017 yaitu check dam 6 yang terletak di Desa Tangkas.
\end{abstract}

Kata kunci: Bangunan Pengendali Lahar, Gunung Agung, Evaluasi Kinerja Bangunan, Kapasitas, Hidrologi

\section{PENDAHULUAN}

Sungai Tukad Unda mengalir dari wilayah hulu di sekitar Gunung Agung Kabupaten Karangasem dan bermuara di bagian selatan di Pantai Gunaksa Kabupaten Klungkung mempunyai luas daerah aliran sungai $230,90 \mathrm{~km}^{2}$ dan panjang sungai utama $22,56 \mathrm{~km}$ (Balai Wilayah Sungai Bali Penida, 2017). Sebagai sungai di daerah vulkanis maka alur sungai ini sering kali dilalui oleh material letusan berupa lahar yang mengalir di sepanjang alur sungai. Berdasarkan admisistrasi Pemerintah melalui Balai Wilayah Sungai Bali Penida, Dinas Pekerjaan Umum Propinsi Bali dan Kabupaten Klungkung serta Karangasem Tahun 2016 telah membangun beberapa bangunan pengendali lahar yang ada di sepanjang alur. Jenis bangunan yang ada diantaranya groundsill, check dam dan konsolidasi dam (Balai Wilayah Sungai Bali Penida,2017) 
Permasalahan yang ada di lapangan adalah inventarisasi bangunan beserta evaluasi kinerja masing masing bangunan pasca erupsi sampai saat ini belum ada. Padahal inventarisasi dan evaluasi terhadap kinerja bangunan yang ada sangat penting untuk diketahui sebagai dasar dalam penyusunan program operasi dan pemeliharaan pada instansi Balai Wilayah Sungai Bali Penida.

Penelitian ini menekankan inventarisasi dan evaluasi penilaian teknis kinerja terhadap bangunan pengendali lahar yang ada. Evaluasi ini menjadi hal yang penting dalam melakukan proses operasi dan pemeliharaan bangunan pengendali lahar secara berkelanjutan. Bangunan yang dioperasikan dan terpeliharan dengan baik memberikan manfaat yang besar bagi masyarakat yang ada disekitar wilayah sungai terutama sekali ketika terjadi erupsi Gunung Agung. Demikian juga dengan operasi dan pemeliharaan yang terartur akan mengurangi tingkat bahaya sekitar sungai serta menekan biaya operasi dan pemeliharaan yang lebih tinggi oleh pemerintah. Survey pendahuluan menunjukkan bahwa bangunan pengendali lahar yang tersebar sepanjang alur Tukad Unda sekitar Sembilan buah bangunan dengan bentang bangunan bervariasi antara 40$60 \mathrm{~m}$.

Berdasarkan permasalahan inventarisasi dan evaluasi kinerja bangunan pengendali lahar yang terdapat di sepanjang Tukad Unda pasca erupsi Gunung Agung dapat disampaikan beberapa sebagai berikut :

a. Berapakah jumlah bangunan pengendali lahar yang ada di sepanjang alur tukad Unda?

b. Jenis bangunan pengendali lahar apa saja yang ada di sepanjang Tukad Unda?

c. Bagaimanakah kinerja dari masing-masing bangunan yang ada pasca erupsi Gungung Agung akhir tahun 2017

Sedangkan tujuan dari penelitian ini adalah untuk melakukan inventarisir serta penilaian kondisi dari bangunan pengendali lahar yang ada. Secara lebih terperinci tujuan dari penelitian ini adalah sebagai berikut:

a. Menentukan Jumlag Bangunan pengendali lahar di epanjang alur Tukad Unda

b. Menentukan jenis bangunan bangunan pengendali lahar di sepanjang alur sungai

c. Memberikan penilaian kinerja masing-masing bangunan

\section{METODE PENELITIAN}

Pelaksanaan penelitian secara garis besar dilaksanakan dalam bentuk pengumpulan informasi (pengumpulan data sekunder dan primer), survei lapangan, analisis permasalahan, serta perumusan inventarisasi dan evaluasi kinerja bangunan pengendali lahar.

Langkah kerja penelitian dituangkan dalam bentuk fishbone diagram tulang ikan yang menggambarkan pentahapan secara utuh dari awal sampai akhir secara berurutan sampai akhir dengan durasi masa penelitian satu tahun.

Survei, Observasi Lapangan dan Pengumpulan Data Lanjutan

\section{Melakukan survei lapangan untuk mengetahui kondisi sungai saat ini, meliputi antara lain:}

a. Pengumpulan data bangunan pengendali lahar

Sebagai sungai vulkanis maka aliran lahar akan sangat berpengaruh terhadap aliran material sungai (Azizah dkk, 2012) 
b. Pengumpulan data pada Kantor Dinas PU Kabupaten Klungkung dan Karangasem, Dinas PU Provinsi Bali dan Balai wilayah sungai Bali Penida terkait dengan studi yang pernah dilakukan dan rencana studi yang mungkin akan dilakukan

c. Melakukan wawancara dengan berbagai elemen terkait dengan penanganan lahar pasca erupsi Gunung Agung.

Sungai vulkanis memiliki karakteristik tertentu dibandingkan dengan sungai alami yang tidak terpengaruh dengan aliran lahar. Sehingga sistem aliran airnya mempunyai ciri yang berbeda (Arthington, 2012)

d. Pengukuran dan kunjungan lokasi

Pengukuran yang dilakukan meliputi lebar sungai, analisis kemiringan, serta

\section{Inventarisasi} bangunan-bangunan pengendali lahar.

Inventarisasi merupakan pengumpulan data terkait dengan lokasi serta kondisi bangunan pengendali lahar yang ada saat ini.

\section{Analisis}

Pekerjaan analisis yang dilakukan meliputi analisis sebagai suatu kesatuan. Adapun analisis yang dilakukan meliputi:

1. Analisis kondisi struktur bangunan

2. Analisis sedimentasi dan volume material lahar

3. Analisis hidrologi untuk menentukan hujan rancangan dan banjir rancangan.

Dalam analisis hujan rancangan dipakai metode Log Pearson Type III ( Kementerian PU, 2000, Sharin, 1990, Soemarto,1985). Sedangkan banjir rancangan dihitung dengan metode Nakayasu (Soemarto, 1985)

4. Analisis hidrolika untuk menentukan besarnya kapasitas sungai dan kapasitas debit pada bangunan serta pengaruh penampang sungai terhadap kemungkinan terjadinya banjir. Da;lam analisis hidrolika diperhitungkan besarnya debit yang terjadi dibandingkan dengan kapasitas sungai yang ada. (Chow, 1987, Brontowiyono,2011)

5. Analisis terhadap kondisi perbaikan dan pengaturan sungai ditinjau dari aspek lingkungan, sistem aliran dan yang lainnya (Sosrodarsono,1987, Maryono 2007,2008, Sukatja, 2017, Arifudin,2014, Soekarno,2009)

6. Analisis evaluasi kinerja bangunan

Analisis ini mendasarkan pada beberapa parameter seperti kondisi sayap, kondisi pelimpah, kondisi lantai hulu dan hilir serta kondisi bangunan lainnya (kementerian PU, 2016)

\section{Metode Penilaian Kinerja Bangunan Evaluasi Kinerja Bangunan Pengendali Lahar}

Evaluasi terhadap kinerja bangunan pengandali lahar dilakukan terhadap beberapa kondisi seperti berikut (Kemen PUPR, 2016, Sukatja 2017) :

1. Kondisi Struktur Bangunan

Kondisi struktur meliputi struktur sayap, pondasi, tubuh pelimpah, kolam olakan, sub dam, pintu air, jembatan perlintasan dan yang lainnya

2. Kondisi fungsi bangunan meliputi kemampuan bangunan dalam menampung sedimen/lahar

3. Kondisi bangunan saat ini dibandingkan dengan gambar dan umur rencana

4. Rehabilitasi yang pernah dilakukan 


\section{HASIL DAN PEMBAHASAN}

Kondisi Daerah Aliran Sungai (DAS) Tukad Unda

Tukad Unda merupakan salah satu sungai besar di Bali dengan aliran yang tersedia sepanjang tahun. Sungai ini mengalir dari wilayah Kabupaten Karangasem di sebelah hulu dan bermuara di Desa Tangkas, Kecamatan Klungkung di Kabupaten Klungkung. Tukad Unda mempunyai anak sungai Tukad Sabuh, Tukad Pedadakan, Tukad Langon, Tukad Barak Ancut, Tukad Yeh Sah Serta Tukad Telaga Waja. Sungai ini memiliki DAS memanjang sejauh 22,56 km dengan luas DAS 230,90 $\mathrm{Km}^{2}$ (Balai Wilayah Sungai Bali Penida,2017).

Penelusuran Sungai/Walktrough Dan Inventori Bangunan Pengendali Lahar

Walktrhrough merupakan kegiatan penelusuran sepanjang sungai untuk memperoleh data-data terkini terkait dengan bangunan pengendali lahar yang ada di sepanjang alur sungai. Dalam kegiatan walkthrough ini diperoleh data-data sebagai berikut: Kondisi exiting sungai dari muara sampai hulu, Inventori bangunan pengendali lahar melintang sungai,Inventori bangunan pengendali lahar di sisi sungai dan data operasi dan pemeliharaan bangunan pengendali lahar di sungai yang ada saat ini.

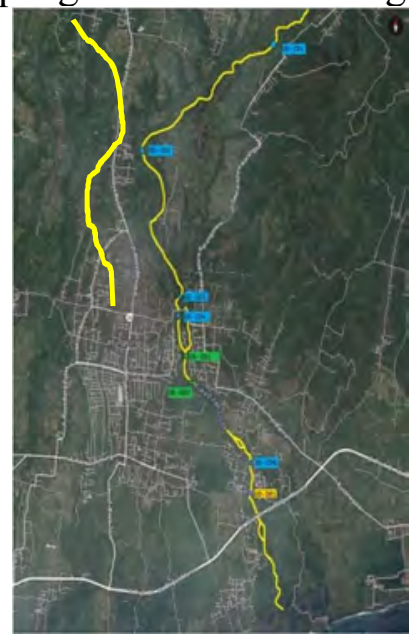

Gambar 1. Plooting hasil inventori Bangunan Pengendali Lahar

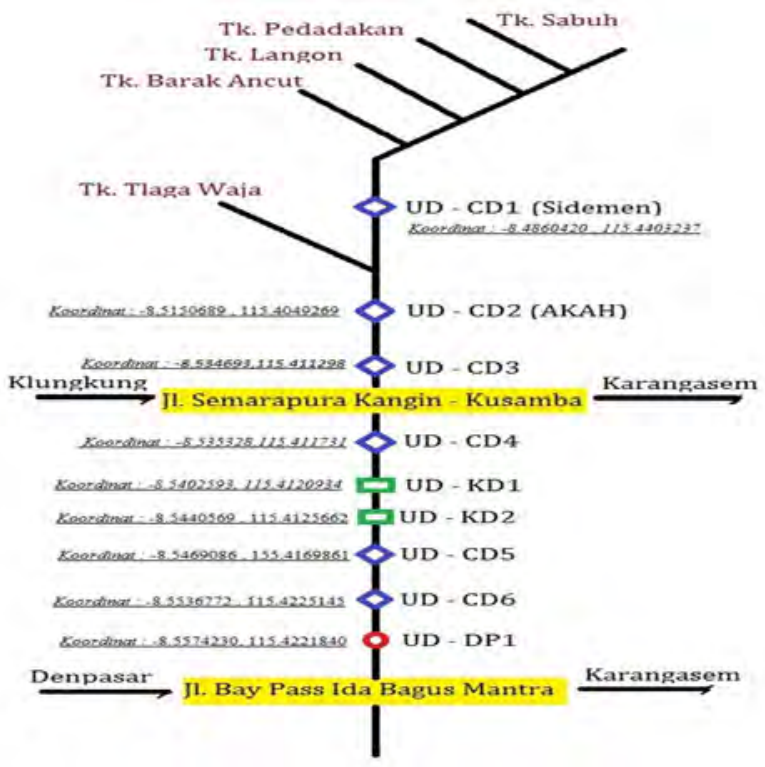

Gambar 2. Skema Bangunan Pengendali Lahar 
Hasil Analisis Hidrologi

Hujan Rancangan

Analisis hujan rancangan dilakukan untul mengetahui besarnya hujan dengan berbagai kala ulang (Sosrodarsono,1987, Harto, 1987, Somearto, 1985) Stasiun yang dipakai adalah stasiun Besakih, Bebandem, stasiun Klungkung dan stasiun Sidemen selama 19 tahun pengamatan mulai tahun 1998 sampai dengan tahun 2017 (BMKG,2017).

Tabel 1. Rekapitulasi Hujan Rancangan DAS Tukad Unda

\begin{tabular}{|c|c|c|c|}
\hline No & $\begin{array}{c}\text { Periode } \\
\text { Ulang }(\mathrm{T}) \\
\text { (tahun) }\end{array}$ & G & $\begin{array}{c}\text { Harga } \\
\text { Ekstrapolasi } \\
(\mathrm{Xt}) \\
(\mathrm{mm})\end{array}$ \\
\hline 1 & 2 & $-0,6996$ & \\
\hline 2 & 5 & 0,5947 & 99,56 \\
\hline 3 & 10 & 1,6147 & 110,56 \\
\hline 4 & 20 & 2,5607 & 115,21 \\
\hline 5 & 25 & 3,0336 & 121,34 \\
\hline 6 & 50 & 4,1981 & 127,56 \\
\hline 7 & 100 & 5,2954 & 138,41 \\
\hline 8 & 200 & 6,4099 & 141,56 \\
\hline 9 & 1000 & 8,8699 & 156,76 \\
\hline
\end{tabular}

Sumber : hasil analisis

\section{Banjir Rancangan}

Analisis banjir rancangan dihitung dengan metode Nakayasu (Sri Harto,1987) dengan masukan utama data luas DAS, Panjang DAS dan koefesien pengaliran.

Tabel 2. Hasil Perhitungan Debit Banjir Rancangan Metode Nakayasu

\begin{tabular}{|r|r|r|r|r|r|r|r|}
\hline \multicolumn{1}{|c|}{ T } & \multicolumn{1}{l|}{ Q2 } & \multicolumn{1}{l|}{ Q5 } & \multicolumn{1}{l}{ Q10 } & \multicolumn{1}{l}{ Q20 } & \multicolumn{1}{c|}{ Q25 } & \multicolumn{1}{c|}{ Q50 } & \multicolumn{1}{c|}{ Q100 } \\
\hline 1,00 & 0,00 & 0,00 & 0,00 & 0,00 & 0,00 & 0,00 & 0,00 \\
\hline 1,00 & 54,02 & 59,46 & 62,38 & 64,41 & 65,45 & 67,34 & 69,10 \\
\hline 2,00 & 299,15 & 329,30 & 345,43 & 356,71 & 362,48 & 372,95 & 382,66 \\
\hline 3,00 & 633,39 & 697,22 & 731,39 & 755,27 & 767,49 & 789,65 & 810,21 \\
\hline 4,00 & 581,07 & 639,62 & 670,97 & 692,87 & 704,09 & 724,41 & 743,28 \\
\hline 5,00 & 472,14 & 519,72 & 545,19 & 562,99 & 572,10 & 588,62 & 603,95 \\
\hline 6,00 & 331,93 & 365,38 & 383,29 & 395,80 & 402,21 & 413,82 & 424,59 \\
\hline 7,00 & 247,44 & 272,38 & 285,73 & 295,05 & 299,83 & 308,48 & 316,52 \\
\hline 8,00 & 190,61 & 209,82 & 220,11 & 227,29 & 230,97 & 237,64 & 243,82 \\
\hline 9,00 & 150,23 & 165,36 & 173,47 & 179,13 & 182,03 & 187,29 & 192,16 \\
\hline 10,00 & 118,78 & 130,75 & 137,15 & 141,63 & 143,92 & 148,08 & 151,93 \\
\hline 11,00 & 93,91 & 103,37 & 108,44 & 111,98 & 113,79 & 117,08 & 120,13 \\
\hline 12,00 & 76,24 & 83,92 & 88,04 & 90,91 & 92,38 & 95,05 & 97,52 \\
\hline 13,00 & 63,08 & 69,44 & 72,84 & 75,22 & 76,44 & 78,65 & 80,69 \\
\hline 14,00 & 52,75 & 58,07 & 60,91 & 62,90 & 63,92 & 65,76 & 67,48 \\
\hline 15,00 & 44,23 & 48,69 & 51,07 & 52,74 & 53,59 & 55,14 & 56,58 \\
\hline 16,00 & 37,09 & 40,82 & 42,82 & 44,22 & 44,94 & 46,23 & 47,44 \\
\hline 17,00 & 31,10 & 34,23 & 35,91 & 37,08 & 37,68 & 38,77 & 39,78 \\
\hline 18,00 & 26,07 & 28,70 & 30,11 & 31,09 & 31,59 & 32,50 & 33,35 \\
\hline 19,00 & 21,86 & 24,06 & 25,24 & 26,07 & 26,49 & 27,25 & 27,96 \\
\hline 20,00 & 18,33 & 20,18 & 21,17 & 21,86 & 22,21 & 22,85 & 23,45 \\
\hline 21,00 & 15,37 & 16,92 & 17,75 & 18,33 & 18,62 & 19,16 & 19,66 \\
\hline 22,00 & 12,89 & 14,18 & 14,88 & 15,37 & 15,61 & 16,07 & 16,48 \\
\hline 23,00 & 10,80 & 11,89 & 12,48 & 12,88 & 13,09 & 13,47 & 13,82 \\
\hline 24,00 & 9,06 & 9,97 & 10,46 & 10,80 & 10,98 & 11,29 & 11,59 \\
\hline
\end{tabular}

Sumber : hasil perhitungan 


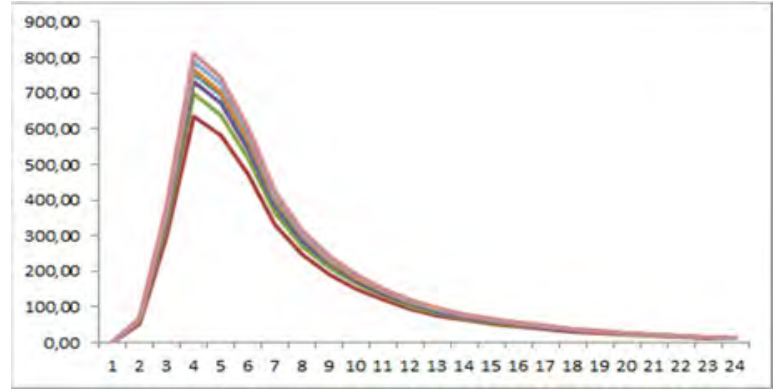

Gambar 3. Hidrograf Nakayasu

Tabel 3. Hasil Analisa Kapasitas Sungai

\begin{tabular}{|c|c|c|c|c|c|c|c|c|c|c|c|c|c|}
\hline \multirow[t]{2}{*}{ No. } & Q rencana & Lokasi & B & $\mathrm{H}$ & A & $P$ & $\mathrm{R}$ & $\mathrm{n}$ & $\mathrm{S}$ & $\mathrm{V}$ & Kap. Sungai & Debit Rencana (Q25) & Keterangan \\
\hline & & & (m) & (m) & $\left(\mathrm{m}^{2}\right)$ & (m) & (m) & & & $(\mathrm{m} / \mathrm{dt})$ & $(\mathrm{m} 3 / \mathrm{dt})$ & $(\mathrm{m} 3 / \mathrm{dt})$ & \\
\hline 1 & Check Dam 1 & Sidemen & 32 & 3 & 96 & 38 & 2,53 & 0,035 & 0,009 & 5,04 & 484,16 & 418,36 & Tidak meluap \\
\hline 2 & Check Dam 2 & Akah & 60 & 3,5 & 210 & 67 & 3,13 & 0,035 & 0,008 & 5,49 & 1153,75 & 592,68 & Tidak meluap \\
\hline 3 & Check Dam 3 & Paksebali & 60 & 3 & 180 & 66 & 2,73 & 0,035 & 0,008 & 5,01 & 900,92 & 662,41 & Tidak meluap \\
\hline 4 & Check Dam 4 & Paksebali & 60 & 3 & 180 & 66 & 2,73 & 0,035 & 0,007 & 4,68 & 842,74 & 679,84 & Tidak meluap \\
\hline 5 & Konsolidasi Dam 1 & Paksebali & 62 & 3 & 186 & 68 & 2,74 & 0,035 & 0,007 & 4,69 & 872,54 & 697,27 & Tidak meluap \\
\hline 6 & Konsolidasi Dam 2 & Tangkas & 62 & 3 & 186 & 68 & 2,74 & 0,035 & 0,006 & 4,34 & 807,82 & 732,14 & Tidak meluap \\
\hline 7 & Check Dam 5 & Tangkas & 65 & 3 & 195 & 71 & 2,75 & 0,035 & 0,006 & 4,35 & 849,22 & 749,57 & Tidak meluap \\
\hline 8 & Check Dam 6 & Tangkas & 65 & 3 & 195 & 71 & 2,75 & 0,035 & 0,006 & 4,35 & 849,22 & 767,00 & Tidak meluap \\
\hline
\end{tabular}

Sumber : Hasil Perhitungan

\section{EVALIASI BANGLNAN PENGENDALLLAHAR}

\begin{tabular}{|c|c|c|c|c|c|}
\hline \multirow{2}{*}{\multicolumn{2}{|c|}{$\begin{array}{l}\text { Nama Banguman } \\
\text { Lokasi Banquanan }\end{array}$}} & \multicolumn{2}{|c|}{ Check Dam 1} & & \\
\hline & & Sidem & $-8.486508,115.439988$ & & \\
\hline \multicolumn{2}{|c|}{$\begin{array}{l}\text { Lokasi Banguman } \\
\text { lispeks dilakukan oleh }\end{array}$} & & & & \\
\hline \multicolumn{2}{|c|}{ Tanegeal pelaksanaan inspeksi } & Mei & Mei 2018 & & \\
\hline \multicolumn{2}{|c|}{ Type bangunan } & Kon: & Konstruks Pasangan Batu & 32.00 meter & $t=12.0$ meter \\
\hline & & & $L=$ & 32.97 meter & $t=200$ meter \\
\hline $\mathrm{No}_{\mathrm{O}}$ & $\begin{array}{c}\text { Bagian bangunan yang } \\
\text { diamati }\end{array}$ & $\begin{array}{c}\text { Hasil } \\
\text { Pengamatan }\end{array}$ & $\begin{array}{c}\text { Tindakan } \\
\text { yang perlu dilakukan }\end{array}$ & $\begin{array}{l}\text { Kondisi } \\
(\%)\end{array}$ & Foto Kondisi Terkini \\
\hline 1 & $\begin{array}{l}\text { Puccak } \\
\text { pelimpah }\end{array}$ & $\begin{array}{l}\text { Beberapa pasangan batu } \\
\text { lepas }\end{array}$ & pethu pertaikan pasangan batu & 85 & \\
\hline 2 & Stating basin & & & & \\
\hline & (kolatil olak) & $\begin{array}{l}\text { tergenus bagian } \\
\text { ujungyya }\end{array}$ & Pertaikun Pasangan & 85 & \\
\hline 3 & Strnktur desar & & & & \\
\hline & banquaan & Baik & Tidak pertu pertaikan & 90 & \\
\hline 4 & Tenbok & & & & \\
\hline & sasap & Baik & Tidakk perlu perbaikan & 90 & \\
\hline 5 & $\begin{array}{l}\text { Pintu } \\
\text { bangunan }\end{array}$ & Tidek ada pintu & & & \\
\hline 6 & Palung sungai & & & & \\
\hline & bagian hulu & Baik & Tidak pertu perbaikan & 90 & \\
\hline 7 & $\begin{array}{l}\text { Papan duzaa } \\
\text { ain (peilschale) }\end{array}$ & Tidak ada piutu & & & \\
\hline & & & Niai Kondisi Rata-Rata & 88 & \\
\hline
\end{tabular}

Gambar 4. Evaluasi Teknis Bangunan Pengendali Lahar: Check Dam 1 


\section{EVALUASI BANGUNAN PENGENDALILAHAR}

Nama Bangunan

Lokasi Bangunan

Inspeksi dilakukan oleh

Tanggal pelaksanaan inspeksi

Type bangunan
Check DAM2

Desa Akah Kec. Klungkung $\quad-8.535247,115.411315$

28 Mei 2018

Konstruksi Pasangan Batu

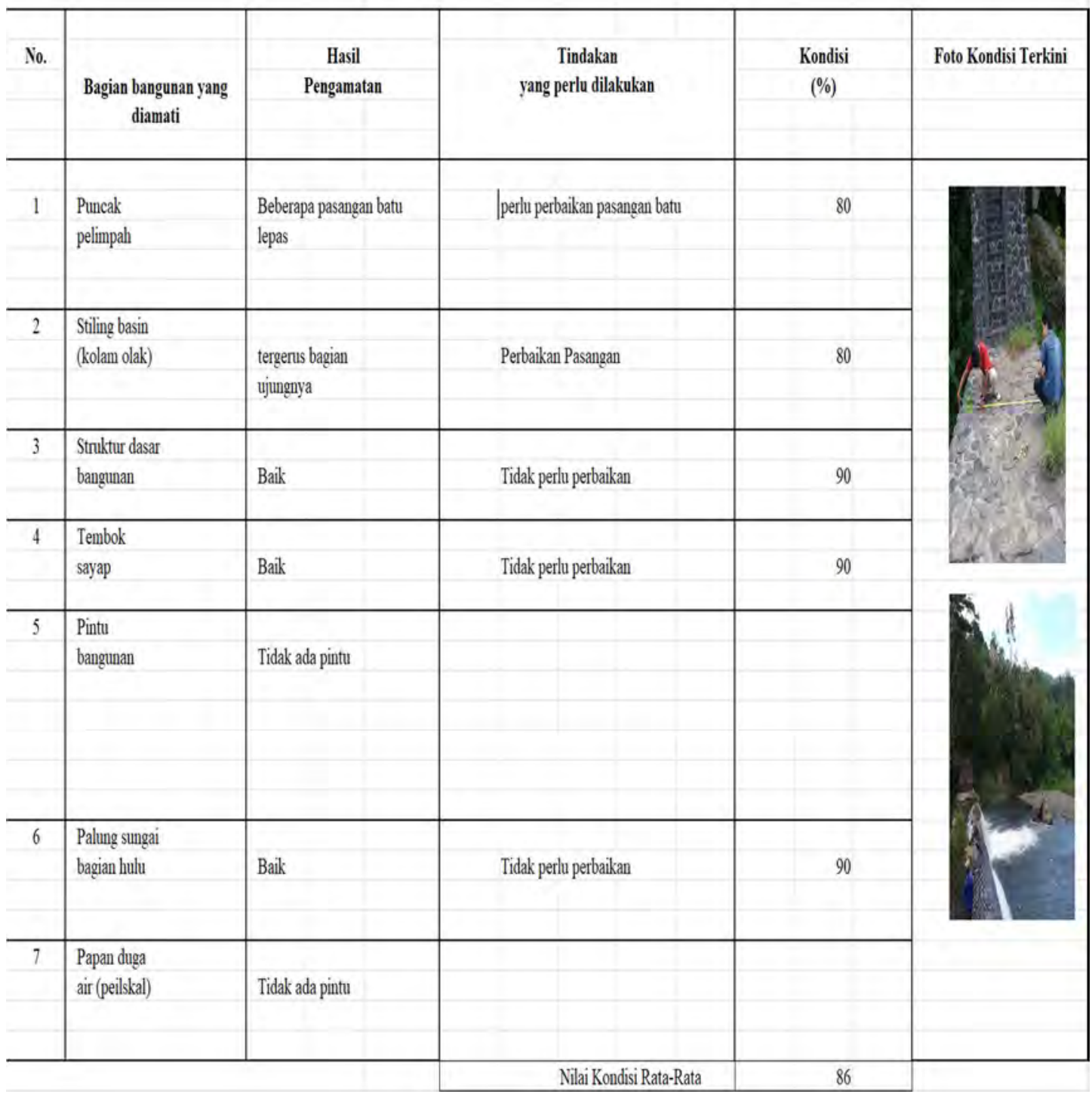

Gambar 5. Evaluasi Teknis Bangunan Pengendali Lahar: Check Dam 2 


\section{EVALUASI BANGUNAN PENGENDALILAHAR}

Nama Bangunan

Lokasi Bangunan

Inspeksi dilakukan oleh

Tanggal pelaksanaan inspeksi

Type bangunan
Check DAM 3

Desa Paksebali $\quad-8.535247,115.411315$

Mei 2018

Konstruksi Pasangan Batu

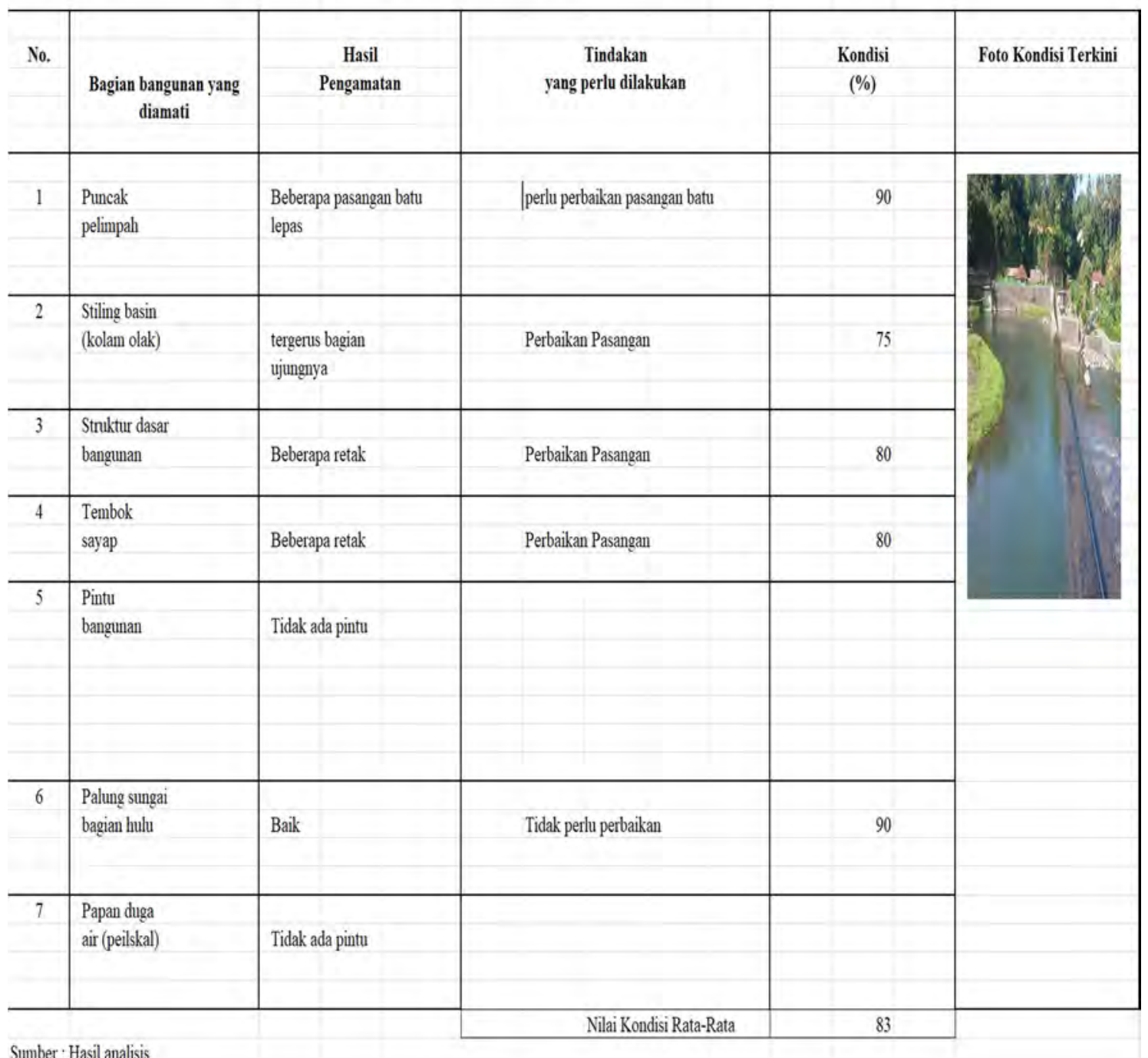

Gambar 6. Evaluasi Teknis Bangunan Pengendali Lahar: Check Dam 3 


\title{
EVALUASI BANGUNAN PENGENDALI LAHAR
}

Nama Bangunan
Lokasi Bangunan
Inspeksi dilakukan oleh
Tanggal pelaksanaan inspeksi
Type bangunan

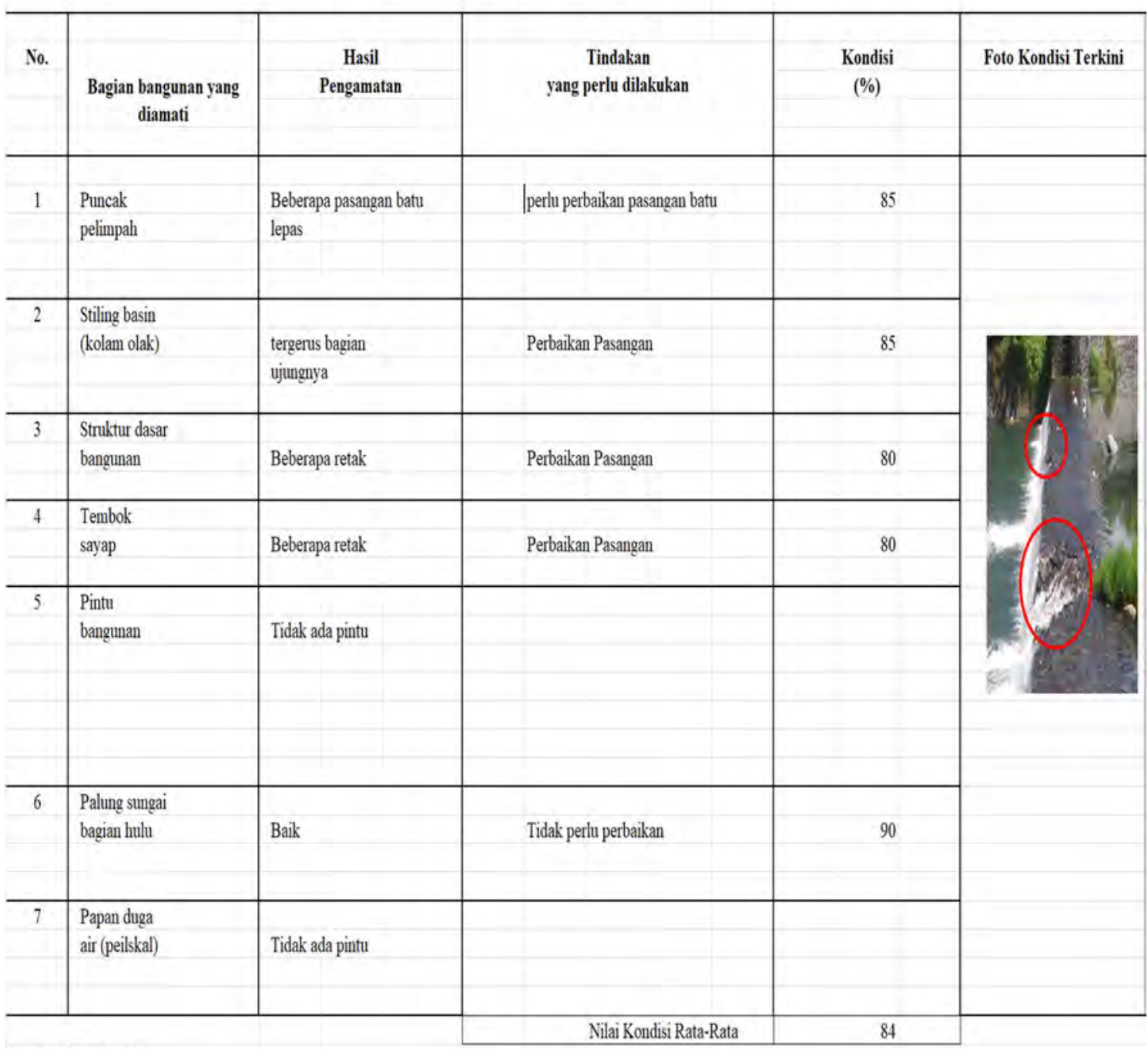

Sumber : Hasil analisis

Check DAM 4

Desa Paksebali

Mei 2018

Konstruksi Pasangan Batu Groundsill

\section{$-8.5352467,115,4113146$}

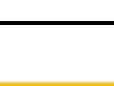




\section{EVALUASI BANGUNAN PENGENDALI LAHAR}

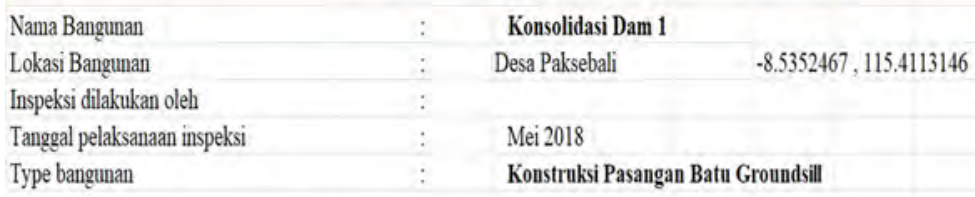

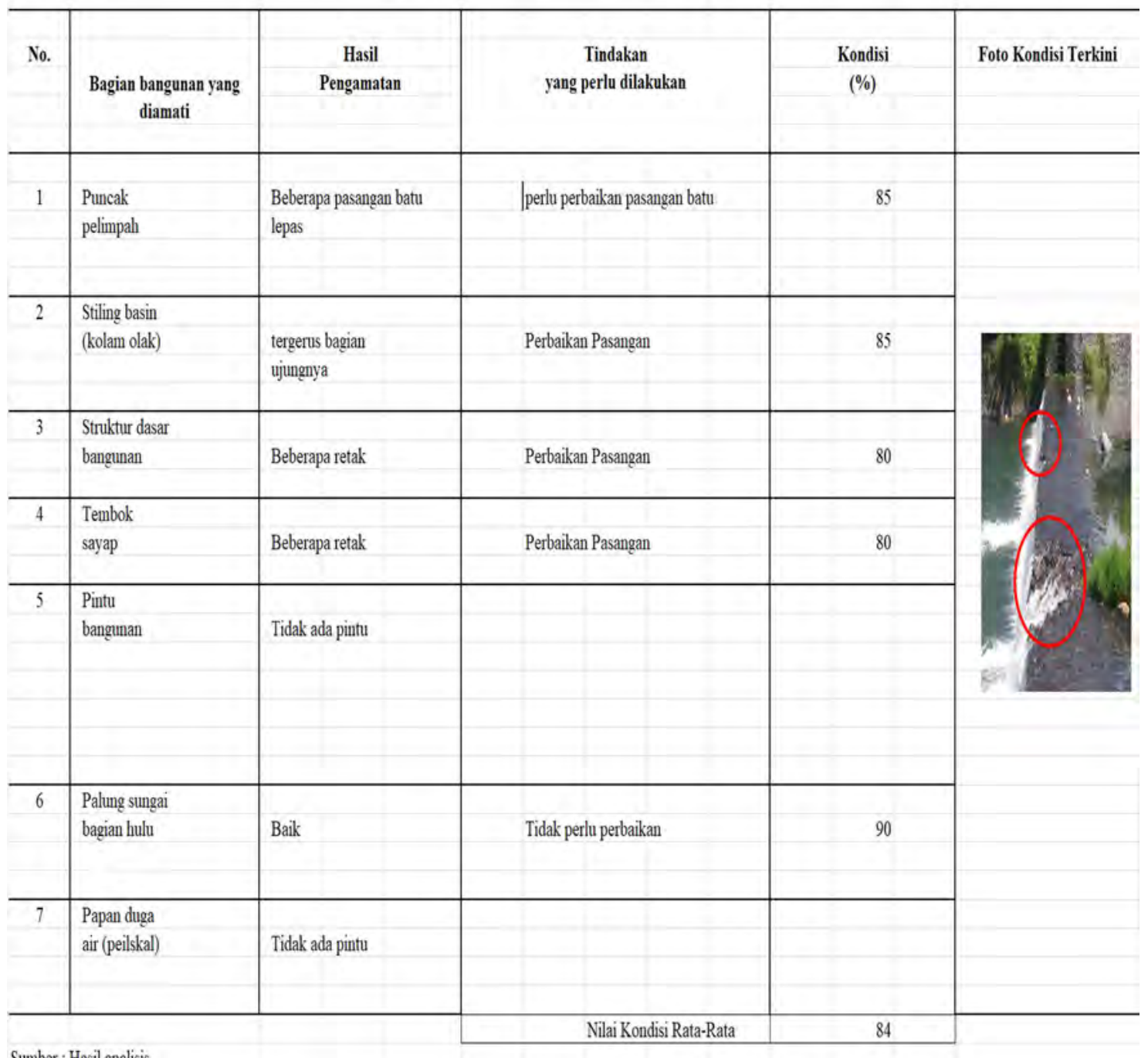

Sumber : Hasil analisis

Gambar 8. Evaluasi Teknis Bangunan Pengendali Lahar: Konsolidasi Dam 1 


\section{EVALUASI BANGUNAN PENGENDALI LAHAR}

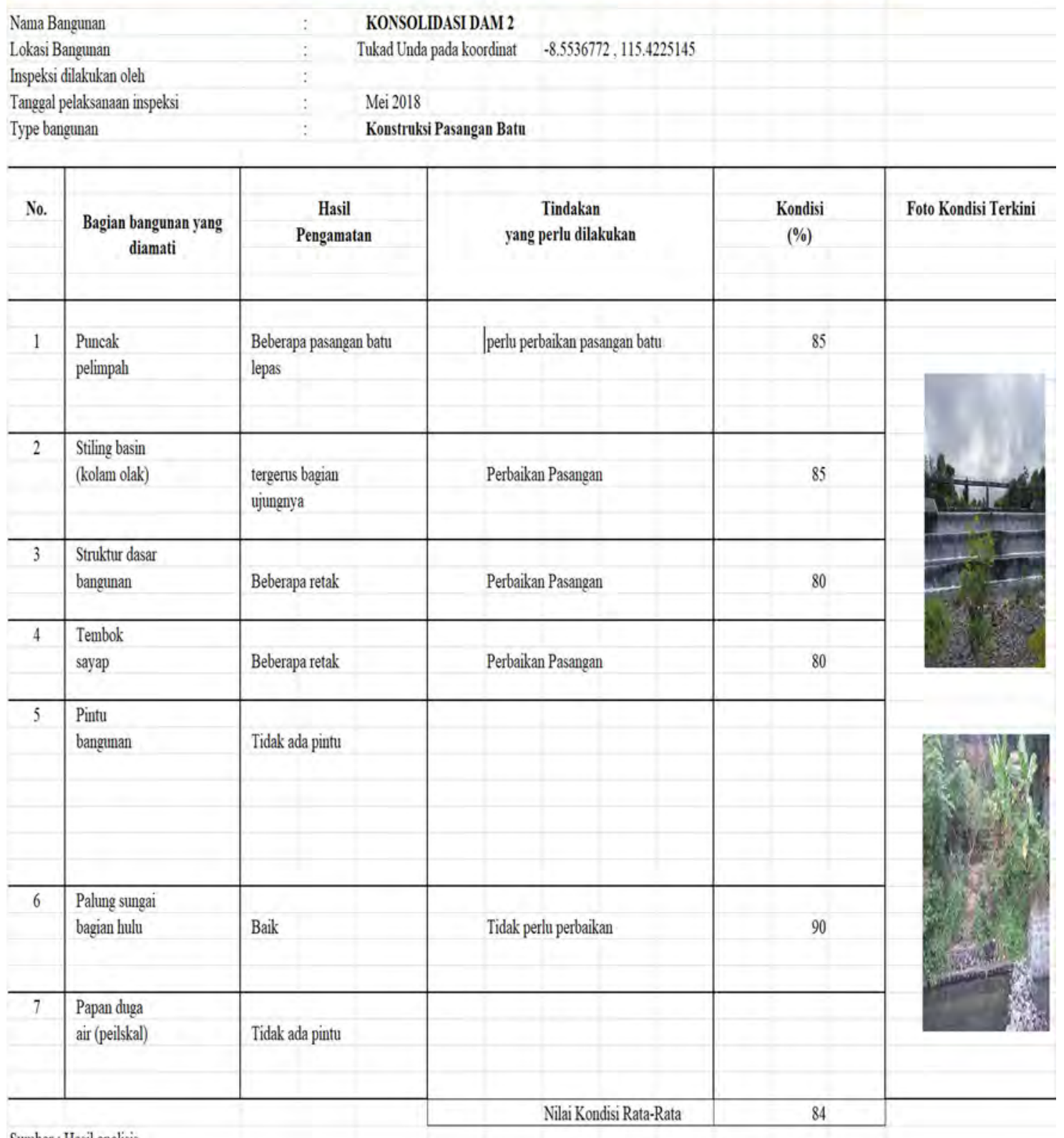

Gambar 9. Evaluasi Teknis Bangunan Pengendali Lahar: Konsolidasi Dam 2 


\section{EVALUASI BANGUNAN PENGENDALI LAHAR}

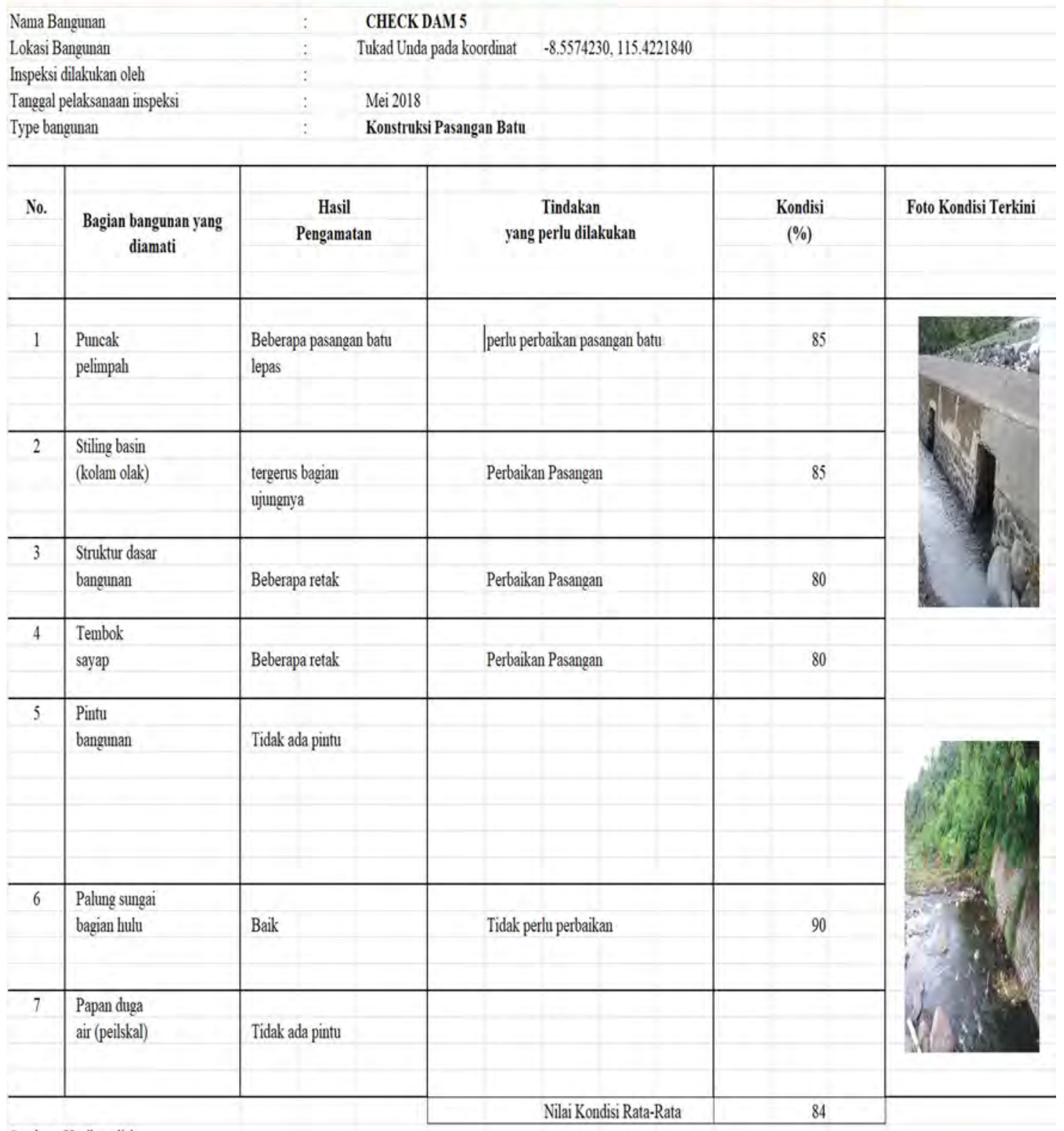

Sumber : Hasil analisi

Gambar 10. Evaluasi Teknis Bangunan Pengendali Lahar: Check Dam 5 


\section{EVALUASI BANGUNAN PENGENDALILAHAR}

Nama Bangunan

Lokasi Bangunan

Inspeksi dilakukan oleh

Tanggal pelaksanaan inspeksi

Type bangunan

\section{CHECK DAM 6}

Tukad Unda pada koordinat $\quad-8.5574230,115.4221840$

Mei 2018

Konstruksi Pasangan Batı

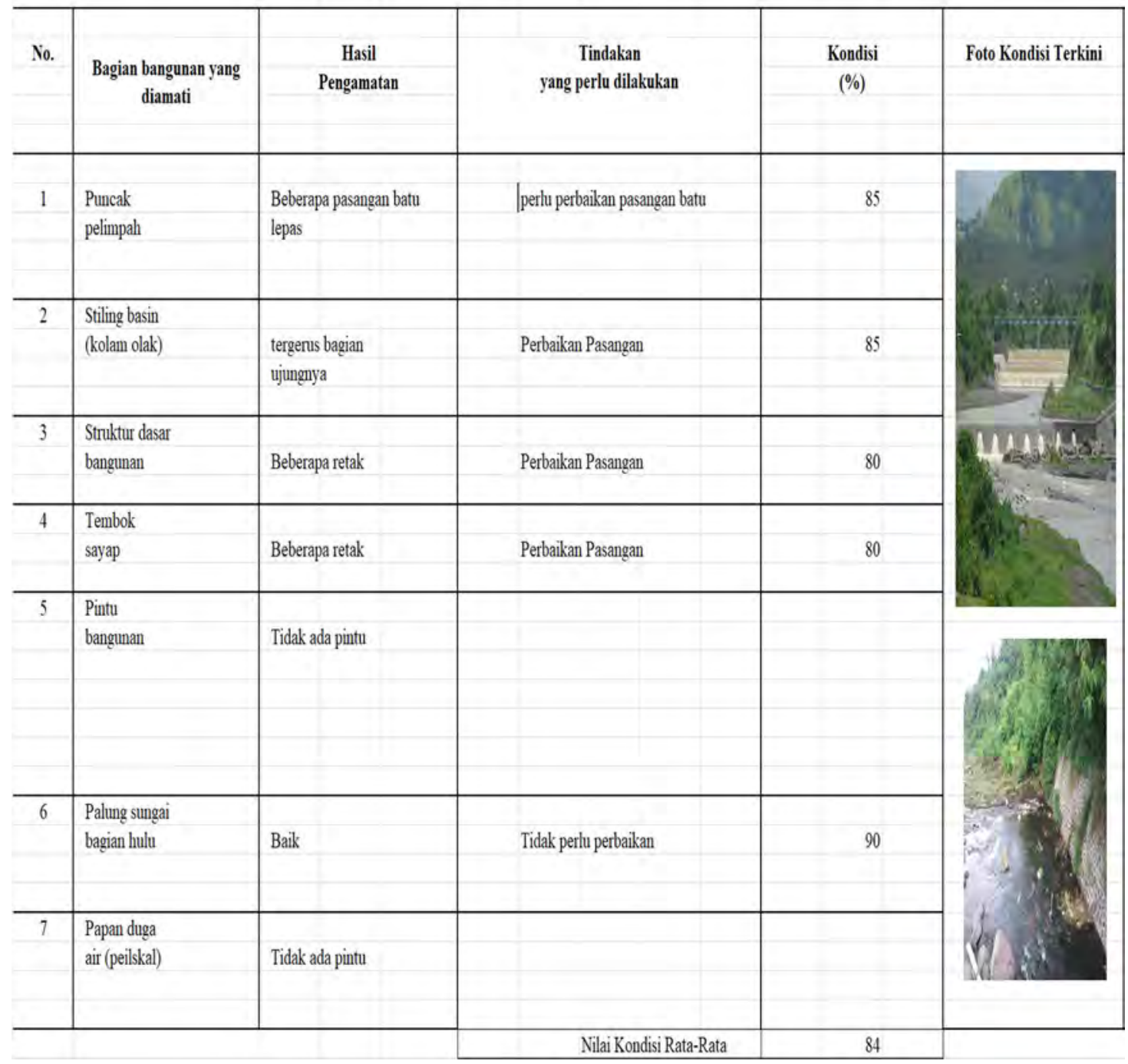

Gambar 11. Evaluasi Teknis Bangunan Pengendali Lahar: Check Dam 6 


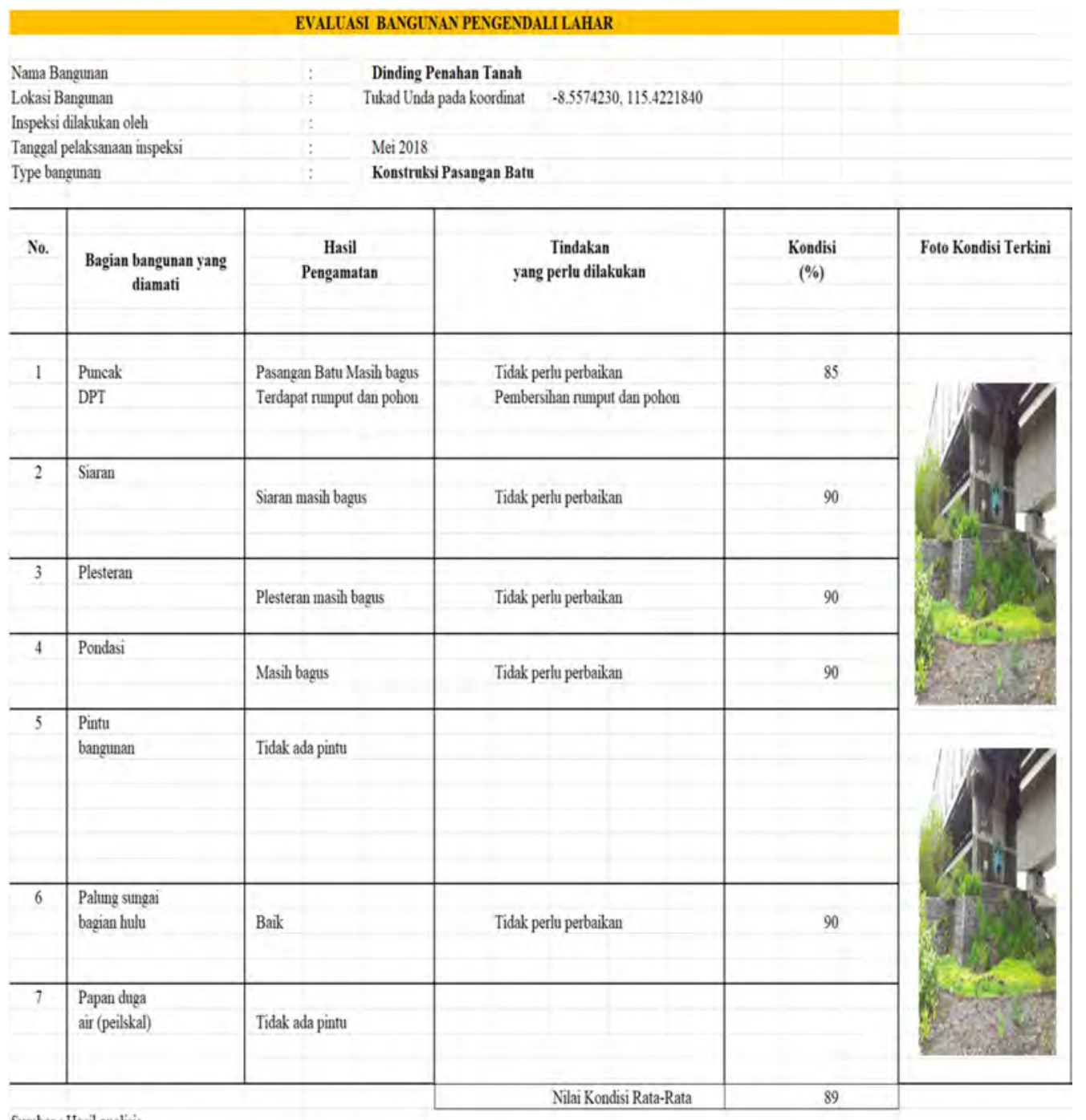

Gambar 12. Evaluasi Teknis Bangunan Pengendali Lahar: Dinding Penahan Tanah

Hasil dari evaluasi teknis bangunan pengendali lahar menunjukkan secara umum bangunan masih berfungsi namun salah satu bangunan yaitu Check Dam 6 hanyut terbawa aliran saat erupsi Gunung Agung. Penilaian secara lebih rinci dari bangunan pengendali lahar yang ada adalah sebagai berikut:

1. Jumlah bangunan pengendali lahar berjumlah 9 terdiri dari 6 buah check dam dengan 2 buah type lubang dan 4 buah type tertutup, 2 buah konsolidasi Dam dan satu buah dinding penahan tanah

2. Kondisi 8 buah bangunan diatas $85 \%$ atau dalam keadaan baik/rusak ringan sehingga hanya memerlukan usaha prebaikan yang sifatnya preventif.

3. Satu buah Check dam dalam keadaan rusak berat karena hancur sampai pondasi yaitu Check dam 6.

\section{KESIMPULAN DAN SARAN}

\section{Kesimpulan:}

Berdasarkan analisis dan pembahasan dapat disimpulkan beberapa hal sebagai berikut :

1. Jumlah bangunan yang tewrdapat disepanjang alur Tukad Unda sebanyak 9 buah. 
2. Berdasarkan jenis bangunan yang ada maka bangunan tersebut dibagi menjadi 3 buah jenis yaitu Check Dam sebanyak 6 buah dengan 2 buah type lubang dan 4 Berdasarkan analisa hidrologi menunjukkan $\mathrm{R} 2=\mathrm{mm}, \mathrm{R} 5=\mathrm{mm}, \mathrm{R} 10=\mathrm{mm}, \mathrm{R} 25$ $=\mathrm{mm}, \mathrm{R} 50=\mathrm{mm}$ dan $\mathrm{R} 100=\mathrm{mm}$. Sementara debit banjir rancangan $\mathrm{Q} 2=\mathrm{m}^{3} / \mathrm{dt}$. $\mathrm{Q} 5=\mathrm{m}^{3} / \mathrm{dt}$. Q10 $=\mathrm{m}^{3} / \mathrm{dt}$. Q25 $=\mathrm{m}^{3} / \mathrm{dt}$. . Q50 $=\mathrm{m}^{3} / \mathrm{dt}$ dan Q100 $=\mathrm{m}^{3} / \mathrm{dt}$. Hasil analisa kapasitas bangunan menunjukkan bahwa semua bangunan mampu melewatkan debit banjir kala ulang 25 tahunan. Ini disebabkan oleh beberapa hal yaitu penampang bangunan yang besar, kemiringan sungai yang tinggi serta kondisi DAS yang masih bagus.

3. Berdasarkan hasil evaluasi teknis kinerja bangunan menunjukkan 8 dari 9 buah bangunan yang ada dalam kondisi yang baik memiliki kinerja diatas 85\%. Sementara satu bangunan chek dam mengalami rusak berat karena terbawa hanyut oleh erupsi tahun 2017 yaitu check dam 6 yang terletak di Desa Tangkas.

\section{Saran:}

Bangunan pengendali lahar sangat berpengaruh terhadap kestabilan aliran lahar dan sedimen sepanjang alur Tukad Unda maka sangat disarankan melakukan penilaian secara bekala dan berkelanjutan.

\section{DAFTAR PUSTAKA}

[1] Arthington, A. 2012. Enviromental Flows, Saving Rivers in The Third Millenium. USA ; University Of California Press.

[2] Aisyah, Nur dkk,2012. Tinjauan Dampak Banjir Lahar Kali Putih Kabupaten Magelang Pasca Erupsi 2010. Yogyakarta : Jurnal Teknologi Technoscienta Vol 5 No.1 Agustus 2012.

[3] Arifudin, Rizaldi dkk, 2014. Studi Pengendalian Banjir Kali Wrati Kabupaten Pasuruan. Malang: Jurnal Teknik Pengairan Vol. 5 No 1 Mei, Universitas Brawijaya

[4] Brontowiyono, 2011. Yogyakarta: Kemampuan Tampungan Sungai Code Terhadap Material Lahar Dingin Pasca Erupsi Gunung Merapi Tahun 2010. Jurnal Sains Dan Teknologi Lingkungan, Volume 3 No.2 tahun 2011.

[5] Kementerian Pekerjaan Umum ,1999. Standar Nasional Perhitungan Banjir. Jakarta: Kementerian PUPR.

[6] Kemen PUPR,2016. Peraturan Menteri No. 115 Tahun 2016 Tentang Operasi Dan Pemeliharaan Bangunan Pengendali Lahar. Jakarta: Sekretariat Negara

[7] Maryono, A. 2007. Restorasi Sungai. Yogyakarta: Universitas Gajah Mada Press

[8] Maryono,A.2008. Eko-Hidraulik Pengelolaan Sungai Ramah Lingkungan. Yogyakarta: Universitas Gajah Mada Press.

[9] Sukatja,2017. Strategi Terpadu Pengelolaan Penambangan Galian $C$ di daerah gunung Merapi. Jakarta: Jurnal Sosial Ekonomi Pekerjaan Umum. Volume 9 no.2 Tahun 2017

[10] Soemarto, CD. 1985. Hidrologi Teknik. Surabaya: Usaha Nasional

[11] Sharin, 1990. Statistical Of Hidrology. Mc.Graw Hill

[12] Sosrodarsono, Suyono \& Takeda, Kensaku 1985. Perbaikan dan Pengaturan Sungai. Jakarta: Pradnya Paramita

[13] Soekarno, Indratmo. 2009. Kajian Hubungan Antara Debit Berubah Dengan Tinggi Muka Air dan Kecepatan Aliran. Bandung: Jurnal Teknik Sipil ITB No. 1 Vol 16

[14] Ven Te Chow, 1987. Open Channel. Mc. Graw Hill 